\title{
Selfish Mysticism, Queer Utopias: 'Homo-ness' in Carlos Hugo Christensen's $O$ menino e o vento
}

\author{
JAMES HODGSON \\ University of Manchester
}

\begin{abstract}
This article considers Carlos Hugo Christensen's film $O$ menino e o vento (1968) through the work of queer theorist Leo Bersani. It argues that Christensen's depiction of same-sex desire makes a fundamental challenge to social organization by reconfiguring the basic unit of interpersonal relations (self and other). Against the well-disciplined homosexual subject, the film presents homosexuality as an impersonal, quasi-mystical, homoerotic force that breaks down and transcends the barriers between individuals, shattering all efforts to name and so to control it. This article addresses specifically the question of queer utopias, sketching out what one might look like in Lusophone cinema. It contributes to the current scholarship on Christensen while examining how ideas about homosexuality are formulated in Lusophone cultures more generally, and how they might be politically useful.
\end{abstract}

Keywords: Queer cinema, homosexuality, Leo Bersani, Brazil, film aesthetics

It is understood that, in general terms, the representation of homosexuality in Brazilian cinema has a tendency to confirm pejorative stereotypes and shore up normative ideas of sexual life, at least up to the 1990 s. ${ }^{1}$ The bicha, or effeminate

\footnotetext{
${ }^{1}$ Although relatively nascent, scholarship on male homosexuality in Brazilian cinema takes a range of theoretical perspectives and positions, and frequently diverges on what counts as a "good" representation of homosexuality. See, for example, Moreno; Hodgson, Male Homosexuality; Subero; Neto; Silva.
} 
male, routinely appears as both a pathologized or clown-like figure and as the default model for male homosexuality, repeating patriarchal and heterosexist sexual norms and cautioning against their transgression. In this article, I will explore what I consider to be a significant exception to this pattern, Carlos Hugo Christensen's film O menino e o vento (1968).

Commentators have noted that $O$ menino e o vento is surprisingly positive in its approach to homosexuality (Moreno 202; Ruffinelli 313). Moreover, it appears to break with the idea of homosexual assimilation (accommodation with the demands of a homophobic social order), and thus might be thought of as being "queer" avant la lettre. ${ }^{2}$ When considered alongside the ideas of Leo Bersani, however, Christensen's formulation of homosexuality makes a fundamental challenge to the way society is organized. This is to say that Christensen's film seems to associate aspects of homosexuality with an antisocial drive, the expression of which undermines conventional understandings of community and reconfigures the basic unit of interpersonal relations, the entanglement of self and other. Joane Nagel writes that ideas about community and belonging are key for larger social structures, including the nation (248). As such, Christensen's film presents homosexuality in a utopian mode that pits itself against a (heterosexist) community, the nation, and beyond. Homosexuality in Christensen's film dispenses with a homophobic, hierarchical society for something new.

This article contributes to the current scholarship on Christensen by examining a film that has not, to date, received much academic attention. ${ }^{3}$ It further expands work on Lusophone cinema by exploring filmic material through a Bersanian lens. Furthermore, by examining the somewhat critical view Christensen seems to proffer regarding forms of homosexual identity in Brazil (specifically the "entendido" identity), I show how the theoretical formulations of Western queer theory have been anticipated in non-Western contexts and cultural objects. In this way, I contribute to a broader effort to look at how ideas about homosexuality are formulated in world cinema (Rowland and Vieira; Hodgson, "Queer Possibilities"; Schoonover and Galt).

\footnotetext{
2 "Queer" is understood here as relating to queer theory, a branch of gender and sexual identities studies influenced by poststructuralism that generally attempts to show how stable categories of (sexual) identity are socially produced rather than essentialist truths (Warner).

${ }^{3}$ Christensen made films in Argentina and Brazil, and scholarship on his work typically focuses on his Argentinian output (García; Gallina; Ruffinelli; Thompson; Melo).
} 
As part of my case for the queer anti-communitarian impulse in Christensen's film, I refer to Bersani's utopian concept of radical "homo-ness." I will set out more fully the concept of homo-ness later in this essay, but a brief summary of Bersani's position on interpersonal relationships will help frame my argument. Bersani expands a classic psychoanalytic position-that most interpersonal relations are founded on a conception of desire as lack — by arguing that this also structures desire around the assimilation of difference. The ego's formative need to incorporate the other, he suggests, means that interpersonal relations are unavoidably informed by aggression, power, and domination, and what follows is an essentially antagonistic standoff between self and other (Bersani, Homos 63; Bersani, Thoughts and Things). In Bersani's view, this doomed entanglement can be circumvented by non-oppositional forms of relating; one such form described in Homos is "self-effacing narcissism," a mode of being wherein one's love for oneself both nourishes the self and dissolves or destroys it at the same time. For the self-effacing narcissist, the other is not presumed to hold tantalizing knowledge that will complete the self (the "missing piece" that torments the classic subject of desire). Instead, he seeks in the other only what he already knows - a version of his own self. This, for Bersani, provides the starting point for a rethinking of relations that avoids an oppositional (self/other) conflict. In the latter half of the article, I consider $O$ menino e o vento through Bersani's theory and explore how far "self-less narcissism" manifests itself in the protagonist, and what this means for the film's sexual politics.

\section{Plot Overview and a Note on Adaptation}

O menino e o vento tells the story of a young engineer, José Nery, who returns to a rural town he visited recently on holiday. Early on, the film reveals that José has been summoned by the local court, and after poor treatment by the townspeople on arrival, the viewer is able to work out that the whole town believes him to have committed a crime. The exact nature of this crime is not revealed to José or the audience immediately (although everyone else seems to know what it is). After he converses with the hotelier and a local judge, we discover that he is being held responsible for the disappearance and presumed death of a local teenage boy, Zeca da Curva, who is supposed to have served as José's guide during his first visit. What makes the crime so appalling is the 
suspicion that the relationship between José and Zeca has a sexual dimension to it, and that the boy's murder is therefore thought to be a crime of passion. Although not illegal in itself (the age of consent in Brazil was, and remains, fourteen, and Zeca is fifteen), the suggestion of homosexuality fuels the town's hatred. This is crystalized in the second half of the film, which is shaped as a trial sequence and, via flashback, relays much of the missing information to the audience. The prosecuting lawyer makes an argument loaded with homophobic aspersion; we are encouraged to read his determination to convict José as synonymous with the townspeople's prejudice. As José takes the stand, he reveals that he and Zeca shared a curious, seemingly nonsexual, spiritual passion for the strong winds that buffet the town. An audience might read the wind as being representative of freedom in some way, perhaps as a general freedom from the town's close-minded and judgmental attitudes, or from the constraints of José's life as an engineer; it is also possible that some viewers might sense a sexual undertone, with the wind representing a freeing of forbidden same-sex desire. José and Zeca pursued this passion together during José's first trip. However, there is more to their shared experience than first meets the eye, and it is eventually suggested that Zeca is in some way a personification or embodiment of the wind, nature, or natural forces. Before the court can make a judgement on José's behavior, the proceedings are disrupted by a powerful gale that clears the room of everyone except José himself, who is left alone, caressing Zeca's shirt.

At the end of the film, the viewer is left with a series of impressions about Christensen's treatment of sexuality that are worth briefly mentioning here. First, it is clear that homosexuality features in the film, specifically with regards to the character of Mário, Zeca's rich bachelor cousin, who attempts to incriminate José during the trial to deflect attention from himself. We are given enough subtext to know that Mário is a closeted homosexual or "entendido" (one "in the know") I will expand this point and its consequences later. At the same time, while the film provides viewers with a variety of homoerotic shot-work, images of male bodies both half-naked and fully nude, as well as a passionate embrace between José and Zeca, it is difficult to determine precisely what is exactly "homosexual" about their relationship, aside from the suggestion of mutual affection, because their interactions are bound up with and articulated through an unusual, shared passion for the town's powerful wind system. This shared passion is ambiguous. One could offer a straightforward reading of it as allegorical, that is, as a covert 
way of addressing homosexual desire without having to name it as such. This would bring the film close to a tradition of homosexual connotation in (primarily Hollywood) cinema that has been examined by David A. Miller. At the same time, an allegorical interpretation does not synchronize particularly well with the way the film presents Mário - after all, if Mário's disguised homosexuality can be signposted to audience, albeit in a closeted way, then why is José and Zeca's desire for each other contrasted to this particular presentation, and concealed behind an elaborate metaphor? It makes more sense to read their desire as an alternative to stable homosexuality, rather than as an analogy.

I want to point out briefly that the film is an adaptation of the short story " $\mathrm{O}$ iniciado do vento," by Aníbal Machado. Scholars have noted that Christensen frequently adapted short fiction for the screen, including work by Jorge Luis Borges and William Irish, often altering these texts to comment on homosexual or homoerotic themes. ${ }^{4}$ Broadly, $O$ menino $e$ o vento retains the setting of "O iniciado do vento," as well as the characters, with a few additions. $O$ menino $e o$ vento is also comparably structured, as the first half of Machado's story is concerned with José's return to the town and the second half an account of the trial. Finally, while much of the dialogue is Christensen's invention, in places he lifts passages directly from his source.

Three differences are worth pointing out: 1) a switch in perspective; 2) alterations to Zeca's age; and 3) the addition of Mário. "O iniciado do vento" is a first-person narrative delivered by "the engineer," a character analogous to José. First-person narrative gives the reader immediate contact with the engineer's thoughts and feelings, and it allows one to see that the engineer is baffled and shocked by the accusations against him. This confirms his innocence. In $O$ menino e o vento, it is the camera that narrates the story, and while the film focuses tightly on José, we are blocked from his thoughts. The result of this that the viewer is immediately less sure of José's innocence. Due to this shift, there is a degree of ambiguity and tension absent from the engineer's story.

A significant change appears in relation to Zeca's age. In Machado's text, the missing boy is twelve years old, while in Christensen's film Zeca's age is

\footnotetext{
${ }^{4}$ A good example of this is A intrusa (1979), adapted from Borges's short story "La intrusa" (Balderston 47). Jorge Ruffinelli notes that Christensen also reworked a short story by North American writer William Irish into two films, No abras nunca esa puerta (1952) and Si muero antes de despertar (1952) (304).
} 
stated as fifteen. For Machado's engineer, age is an important marker of difference, which he uses to define himself against the boy:

As rajadas aumentavam empurrando-me para o espaço, como que me desafiando a imitar a proeza do pequeno companheiro. Não. Eu, não! Sou engenheiro, não sou criança. Construo pontes, tenho os pés fincados na terra... Loucura, querer emular-me com o garoto. Tratei de sair dali. Amanhã, pensei, amanhã saberei onde o largou a ventania. (Machado 29)

For Christensen, narrowing the age gap between José and Zeca dilutes an implication of pedophilia while also making a potential sexual relationship between Zeca and José legal. I argue that one of Christensen's approaches to homosexuality centers on the visual similarity between José and Zeca, and a reduced age gap helps facilitate this by lessening their physiological difference.

The third important change made in adaptation is the addition of a new character, the aforementioned Mário. In the next section, I will comment in detail on the way Christensen contrasts Mário's closeted but stable homosexuality with José's sexual ambiguity, but to summarize here, I suggest that Christensen transforms Machado's text in order to set up two distinct modes of homosexuality: first, by enabling or enhancing a sense of similarity between José and Zeca; and second, by contrasting the sexually ambiguous José with the closeted figure of Mário.

\section{Visualizing Sexual Investigation}

During the first half of the film, Christensen presents the townspeople as conflicted, paranoid, and hierarchical, as well as explicitly homophobic, and furthermore paints the "entendido" as a figure complicit with a violent and oppressive social order, much of which is conveyed to audiences through camerawork, lighting, and framing. ${ }^{5}$ To unpack this claim, in this section I want

\footnotetext{
5 The term "entendido," or "one in the know, one who understands," has multiple but related meanings. It is used to signify anyone who is aware of the homoerotic subcultures that emerged from the 1950s onwards. It is an umbrella term for individuals, most often of the middle classes, who adopt a gay or homosexual identity, and also for those who do not class themselves within the
} 
to examine cinematographic aspects of three sequences: the introductory sequence, José's meeting with his lawyer, and José's meeting with Mário.

The film opens with José's journey as he travels by train to the unnamed rural town. Shots of passengers engaged in "normal" life - a couple kissing, an elderly man asleep, a woman knitting - are contrasted with an uncomfortable José, which marks him, subtly, as somehow different. Then, a rock is thrown at José through the window; the other passengers panic and leave his carriage. Their withdrawal is mirrored by the camera, which pulls back from him in a comparable way to the passengers, aligning the viewer with the latter group and signaling José's otherness. When José arrives at his destination, his train is quickly surrounded by a large group of townspeople who, we infer, have gathered at the platform to see him. The mob fills the frame; a high-angled camera position with José in the crowded midground both create an atmosphere of suffocation and position the audience with the townspeople as spectators to his arrival. We are strangely distanced from the film's protagonist, our identification further impeded by the fact that the heavy wooden paneling of the train carriage repeatedly breaks up the shot and separates José from the viewer.

Some of Christensen's lighting and framing choices are clearly drawn from film noir, a link that can be seen in the deliberate use of heavy shadowing, or chiaroscuro, to present the town and its inhabitants. As Janey Place and Lowell Peterson write, "it is the constant opposition of areas of light and dark that characterizes film noir cinematography" (30). Of course, O menino e o vento does not fit the film noir mold exactly, at least in terms of the genre's major narrative conventions (an urban setting, a "hard-boiled" protagonist, and so on), but Christensen nonetheless uses low-key lighting in a comparable way, that is, to dramatize a struggle between opposing forces, to code the town as a polarized and divided space, and to isolate the protagonist. ${ }^{6}$ As José is driven through the

categories that emerged from the binary logics of the traditional model of sexuality but nonetheless engage in the sexual community enough to be considered aware or knowledgeable of it. James Green suggests that alongside the rejection of a bicha comes conformity to standards of social visibility. In other words, a self-defining entendido trades exemption from stigma, inherent in the application of an active/passive, male/female dyad to same-sex relations, for a certain degree of "closeted-ness" and invisibility (192). Néstor Perlongher dates the term to 1964-65 as used in avant-garde theater circles "para amenizar" (18).

${ }^{6}$ A basic lighting setup uses three individual lights to illuminate an actor: the "key light," or principal light source, which in classical cinema was positioned high up and forty-five degrees to an actor; the "fill light," positioned near the camera and used to soften the harsh shadows produced 
streets by his police escort, a series of shots depict the town's walls and pavements as brightly lit but also cut across by strong, crisp shadows (Figure 1).

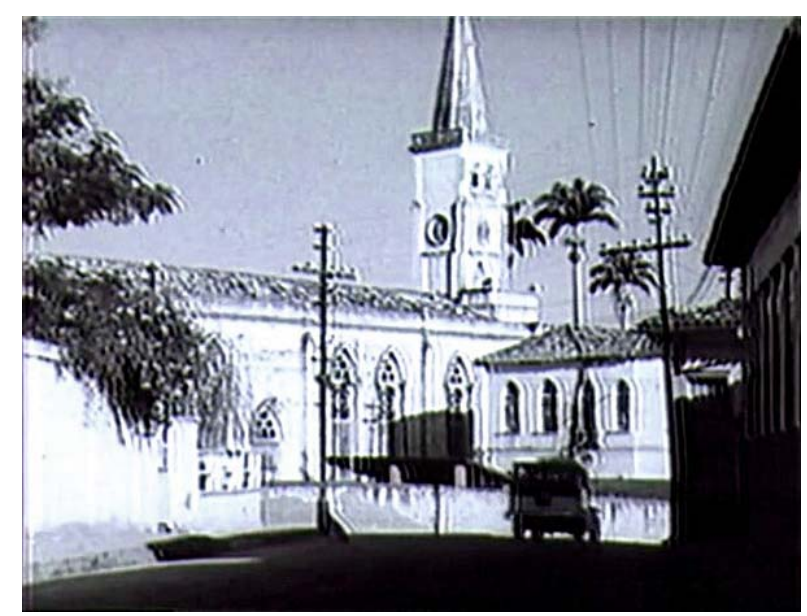

Figure 1: The town is starkly lit when José arrives for his second visit, at the beginning of $O$ Menino e o vento. (C) Carlos Hugo Christensen Produçoẽs Cinematográficas.

When he arrives at his temporary accommodation (the same hotel he had stayed at during his first trip), a group of townspeople emerge from the heavy shadow dominating the town's plaza and begin to chant in unison about murdering José (Figure 2). The stark lighting emphasizes the unusual emptiness of the streets and gives an exceptional quality to José's visit, as if the whole town has suddenly come to a stop. Conversely, the harsh shadow hints at the town's underlying violence. The use of chiaroscuro builds atmospheric tension while framing the threat the townspeople pose to José in terms of strict, binaristic oppositions: light/dark, familiar/foreign, and group/individual. This oppositional motif is replicated in shot composition and framing; when the mob approaches José at the hotel, for example, Christensen sets up the mise-en-scène with the balustrade, a car, and a police constable's body dividing José off from the angry townspeople. The town is consistently shown as a space fraught with division, stratified by barriers that seem both to protect José from simmering aggression and to enforce

by the key light; and the "back light," positioned behind the actor and used to differentiate him or her from the backdrop. In high-key lighting, a small ratio of key light to fill light evenly illuminates the actor, while in low-key lighting the fill light is reduced, thus intensifying the shadows and contrast created by the key light (Porfirio, Silver, and Ursini 66). 
a strict social order. The tension of the introductory sequence is also amplified by the fact that the mob's behavior is inexplicable to the viewer (up to this point), both unwarranted and unpredictable.

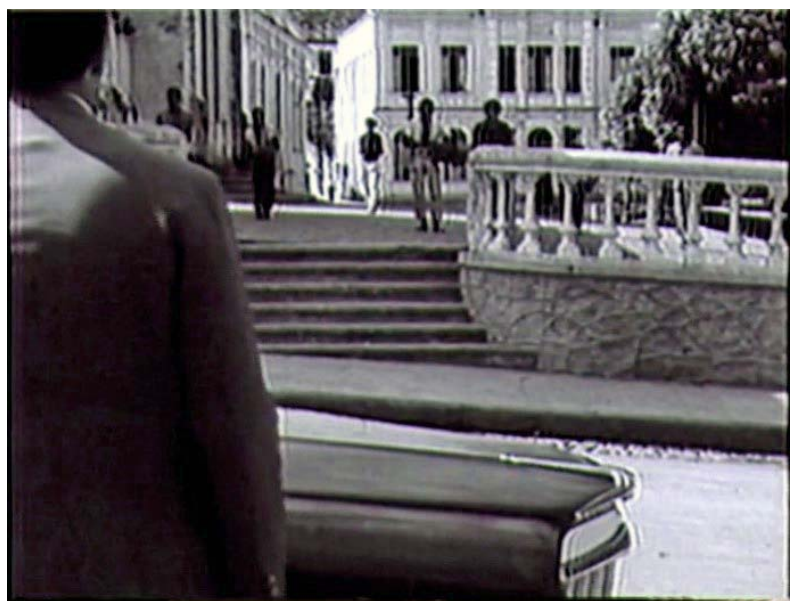

Figure 2: The mise-en-scène is divided and structured, suggesting similar divisions run through the town's social environment.

(C) Carlos Hugo Christensen Produçoẽs Cinematográficas.

In general terms, then, the camerawork seems to hold José at arm's length from the viewer while nonetheless positioning him as object of extreme interest. When José meets with his lawyer, some of the connections between the film's visual strategy and sexual identity become clearer. The premise of the film is spelled out when José meets with his lawyer: José is told that he has been summoned to account for Zeca's disappearance, and he will have to give testimony on this matter in court the next day. Although employed to defend José, the lawyer is clearly antipathetic towards his client—he tells José "seu crime é bárbaro" and underlines the crime's sexual component, "o lado sexual." The zoom shot executed when the lawyer introduces this detail combines the camera's gaze with the gaze of the lawyer, in much the same way as the camera has been aligned with the townspeople at points in the previous sequence. The emphasis placed on José's face is, arguably, resonant of an attempt to read his face for signs of guilt, and so to treat José as an object of investigation, specifically in relation to a sexual crime. This shot could be understood as linking the intrusive, isolating, and investigative camerawork to a question about his 
sexuality, and in particular to a question of unresolved or unknown sexuality: José's otherness is in some way sexual otherness. When coupled with the lawyer's disgust, one might also read the visual and social othering as to some degree homophobic, insofar as both processes are efforts to isolate, contain, and resolve (abject) sexual deviance. Rather than affirm or deny homosexuality, José remains silent and ambiguous. This unresolved ambiguity incites narrative tension by eliciting our curiosity, but it also helps fuel the plot-if José does not confess to his lawyer, he will be expected to confirm either a hetero- or homosexual identity on the stand, which gives the narrative its hook. Of course, it is worth pointing out that the charge against José is murder, not homosexuality on its own. ${ }^{7}$ Rather, as the court case develops later on, it is clear that the case against José rests on confirming his homosexuality so as to prove motive; the townspeople, and later the jury, become invested in establishing the truth about José's sexuality in clear, unambiguous terms.

The impetus to clarify and classify José's sexuality is crystalized in the introduction of Mário, Zeca's cousin, who approaches José partway through the film's first half and invites him to meet outside town. He proposes to help José by providing him with an alibi for the crime - the catch is that José has to confess his sexual interest in Zeca to him, or at least affirm his homosexuality. Not only does Mário assume José is a homosexual and completely accepts the sexual nature of his relationship with Zeca, but he also suggests that José is innocent of the murder itself: "pelo menos da morte, e o resto não é crime." In coded language, Mário reveals that he too is homosexual. He says that minority groups have to defend their own kind from the "normais," and then goes on to reveal he threw the rock at José in the film's opening sequence in order to deflect attention from himself. In this respect, Mário's closeted but accepting perspective on homosexuality can be seen as exemplary of the "entendido" figure-masculine, bourgeois (described by Zeca as "cheio da grana"), and clandestine. José refuses to confirm (or deny) any sexual interest in Zeca, rejecting Mário's offer; the two men have a brief argument before Mário leaves.

This sequence is curious because Christensen seems to draw subtle parallels between the townspeople and Mário, despite the latter's sense of being in conflict with "normal" people. As the sequence begins, our attention is drawn to the

\footnotetext{
${ }^{7}$ Homosexual activity has not been illegal in Brazil since the 1830s (Trevisan 68).
} 
similarities between José and Mário, particularly in terms of physical appearance and class. This is an effect created in part through costume choices but also through a series of close-up shot/reverse shots that include both men in the same shot and, with a tight focus on their faces, work to emphasize their bodily (facial) sameness (Figure 3 ). The close focus and physical proximity connote a degree of intimacy, and they mitigate some of the contrast produced by low-key lighting. However, as the conflict between the two men comes to the fore, changes to the mise-en-scène emphasize their difference: they physically separate from each other so that each actor comes to occupy a shot on his own; José's face is evenly lit, while stark shadow covers Mário's face and brings his dark outline, almost a silhouette, into relief against the pale sky (Figure 4). This reminds the audience of the chiaroscuro lighting that dominated the town during the film's introduction and, at the very least, serves to emphasize the sense of José's renewed isolation. But it also contributes to an impression that Mário is ultimately complicit with the townspeople in his diversionary tactics, in his insistence that José openly confess his homosexual desire, and finally, visually, in his visual association with shadow.

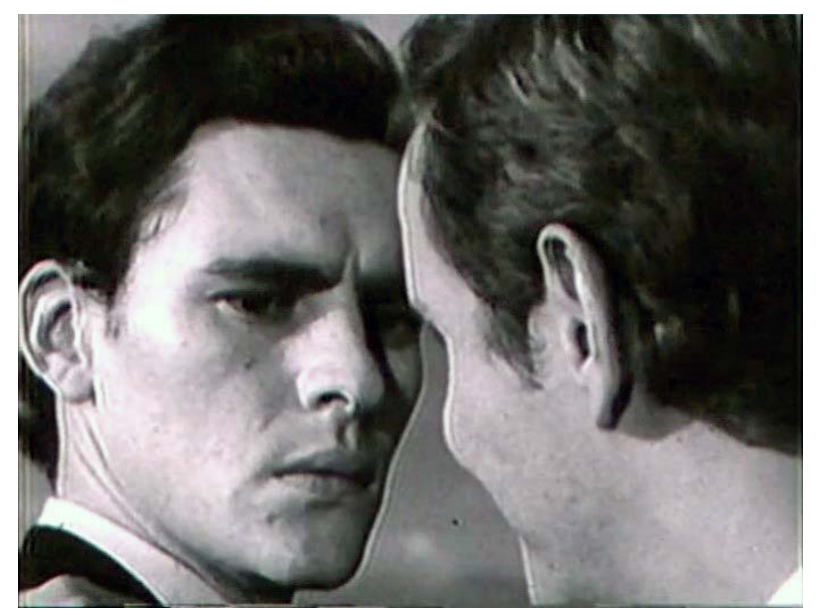

Figure 3: Mário and Jose seem to be two of a kind. (C) Carlos Hugo Christensen Produçoẽs Cinematográficas.

The sequence can justifiably be taken as a commentary on the Brazilian "entendido" identity, which is premised on remaining in the closet, "passing" as masculine, and rejecting the associations between homosexual desire, a 
presumed sexual position, and a gender identity (attributed to homosexual men, or "bichas," who were broadly understood to be sexually passive and effeminate) - connections made as part of what James Green has called the "traditional" or "popular" model of homosexual classification in Brazil (192).

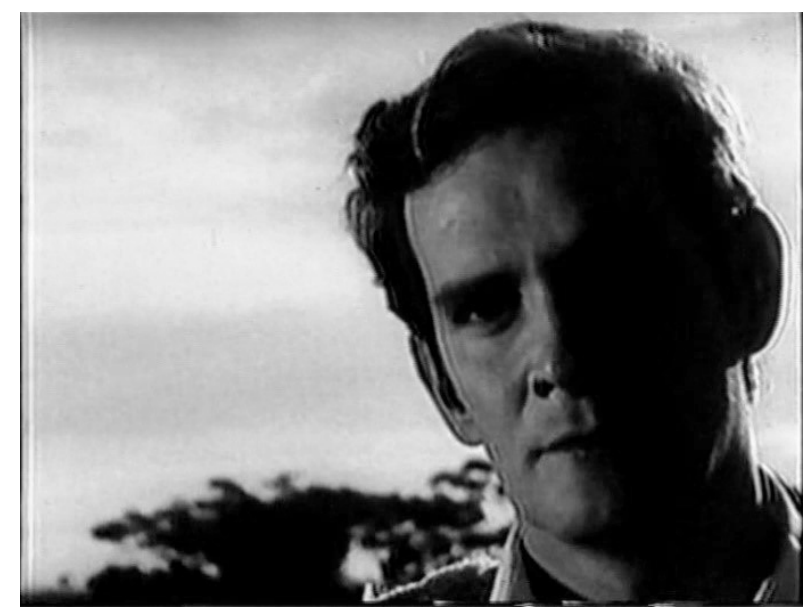

Figure 4: Mário's true colors are suggested when José refuses his help. (C) Carlos Hugo Christensen Produçoẽs Cinematográficas.

Christensen appears to suggest that although the "entendido" escapes persecution via the closet, he nevertheless participates in and enforces potentially oppressive or problematic social relations. For example, Mário espouses oppositional politics in his description of one group pitted against another (a "nós" that must defend against the "normais"). For this model to function, group members are required to affirm a shared identity, a fact that helps to explain why José's continued ambiguity is tricky for Mário: his reluctance to accept either group identity keeps clear oppositions from being drawn. The framing of sexuality in this way also invokes a sense of hierarchy, with a dominant sexual majority that oppresses a minority. In that sense, his dialogue echoes the visual presentation of the town's hierarchies and divisions. Finally, Christensen seems to suggest that homophobic violence is displaced by Mário's closeted status (the "entendido" has a vested interest in deflecting suspicion rather than challenging prejudice), as Mário explains why he threw the rock: "Não quero que ninguém suspeite de nós."

One can trace implicit connections between Mário's position as an "entendido," his desire for José to openly affirm some kind of sexual interest in 
Zeca, and the broader significations attached to the townspeople both in terms of their on-screen behavior and their visual presentation. The first half of Christensen's film presents the town in terms of a divided, hierarchized social order. The "entendido" Mário is able to survive within this space because by remaining in the closet he both conceals himself and implicitly supports the structure that underlies the town's social fabric, namely, its hierarchically arranged identities and groups. For Mário to extend a similar protection to José, he requires him to accede to a group identity ("nós"), which logically means accepting the hierarchies of the status quo. The lawyer makes an equivalent demand earlier in the film - that he can only help José if he outright confirms or denies the sexual aspect of his relationship with Zeca. Both the lawyer and Mário require José to clarify his sexual desire in binary or dualistic terms so as to conform to the oppositional structure characterizing the town's status quo. But in both cases José refuses to do so. As I have suggested above, his sexual ambiguity has an obvious narrative role because it keeps the viewer interested in José's motivation, that is, whether or not he really desires Zeca. His ambiguity also provides the ground for Christensen to sketch a utopian form of sexuality that resists oppositional structures in the second half of the film.

\section{Homo-ness: Desire for the Same in the Other}

In order to understand how Christensen's film might be seen as challenging an oppositional model of identity, I will provide a brief overview of Bersani's work on homosexuality, set out in Homos (1995). According to Bersani, queer theory provides a heuristic for working out how heterosexuality becomes normalized and promoted within institutions and cultural products, but as a consequence of its emphasis on social construction it can erase any specificity attached to homosexual desire, and so, among other things, inadvertently undermines how a subject might resist oppression (Homos 7). To retrieve this lost specificity, Bersani turns to Freud's account of the psyche. First, he explores the heterosexual male psyche as involving in its earliest development a traumatic encounter with the other, which is formative insofar as all subsequent encounters with the other are framed as defensive or antagonistic, as sketched briefly in the introduction to this article. This leads Bersani to the insight that oppositional relations between self and other, being historically aggressive or traumatic, are also implicitly 
hierarchic. In these contexts, the self and other enter into perpetual contestation for domination. Conventional self-other relationality therefore produces what Bersani calls "heteroized society" - another term for heterosexist patriarchywhich promotes and sustains hierarchy and prevents by default the emergence of any truly egalitarian existence (Homos 39).

Bersani takes the Freudian model of male homosexuality, seen as an alternate model of relationality, focusing specifically on the particular way in which desire shapes the homosexual subject. Freud famously describes the origin of male homosexuality as a deviation from normal sexual development that takes place in childhood. As is well known, in this account, male heterosexuality is formed by the child taking the mother as his love object, and subsequently repressing this desire due to the father's threat of castration, before finally identifying with the father. Bersani views this as a "traumatic privileging of difference" and as producing desire in terms of lack; the resulting subject's desire is essentially based on the incorporation of the other. In male homosexuality, the child identifies with the mother rather than the father, which then leads to the child taking his own self, or ego, as love object. Desire, in other words, is directed towards sameness, founded in a narcissistic love for the same, and experienced by a self that has become othered to itself in its identification with the mother. In Bersani's work, it is this unique formulation - self-love that emerges alongside a nonaggressive identificatory relationship with otherness-which holds the potential for an alternative to "heteroized" society.

Against straight hierarchical relationality Bersani pits "homo-ness." Broadly, homo-ness involves an investment of desire in the self, as in classic narcissism, but in such a way that sees the self expand its boundaries to the point where it is no longer recognizable as a self. Homo-ness is self-love coupled with selferasure, and comes with the advantage of leaving otherness unthreatened, as merely supplementary to self-expansion. Bersani finds homo-ness in the work of three homosexual writers, including André Gide, although he is eager to stress that this does not limit the concept to gay men (Homos 8-9). The narrator of Gide's The Immoralist, Marcel, finds that his love for the male adolescents in Morocco actually activates a more profound love for his own body, which takes the shape of a "narcissistic expansion of a desiring skin" (Homos 124-25). As this skin unfolds, it serves to expand Marcel's sense of self outward, dramatically blurring the boundaries between his psyche and the natural world. According to 
Bersani, such expansion inhibits the aggressive self-preservation that is typically associated with classic narcissism (125). It is of particular interest to this paper that Marcel's experience of homo-ness puts him in contact with "the soil, the grass, the air" (120), given that José's desires for and experiences with Zeca also engender an ecstatic, egoless communion with nature. It is also of interest that it is self-love-homosexual desire for the same - that triggers homo-ness in The Immoralist rather than explicit sexual activity, given that José and Zeca do not consummate their relationship on screen in any way, but nonetheless find the presence of the other pleasurable.

\section{Homo-ness and the Eroding of Difference}

Bersani's ideas can help illuminate some of the more puzzling elements of $O$ menino e o vento, particularly the ambiguous relationship José develops with Zeca. I also make use of his theory as a way to make sense of the changes in style that characterize the second half of the film, where it is arguable that Christensen shifts his cinematography from an approach that stresses difference to one that emphasizes similarity.

As I have mentioned above, the film can be said to have two parts - the first being the buildup to José's trial, which includes his arrival in the town and his encounter with Mário, and the second being the trial itself, which, although technically set in the courtroom, includes numerous flashbacks that set out the details of what happened before Zeca disappeared. The shift in cinematography between parts can be seen in a straightforward way when José recounts his arrival at the town for the first time: the town's geometric division between light and dark is replaced by a diffusely lit urban space (Figures 5 and 1). This sequence also begins to trouble the differences between Zeca and José. Zeca is first hired to carry José's bags, but the two characters quickly discover that they share a mutual passion for "the wind," which one might take as a synecdoche for a love for nature or for the wildness and freedom found in it. This common interest lays the ground for mutual affection, but it also hints at deeper similarity, one that Zeca points to as he explains the etymology of his name. He calls himself Zeca da Curva, "porque eu sempre morei lá encima na curva, desde que eu nasci," but states that in reality his name is José da Paiva. Zeca is a colloquial version of Zé, itself a contraction of José. It is also worth pointing out that the equivalent 
character to José in Machado's short story is simply called "the engineer." Christensen has deliberately selected José's name and clued the viewer in to the way "Zeca" finds its root in "José" so as to illustrate in a small but significant way how apparent difference contains or belies a more profound resemblance.

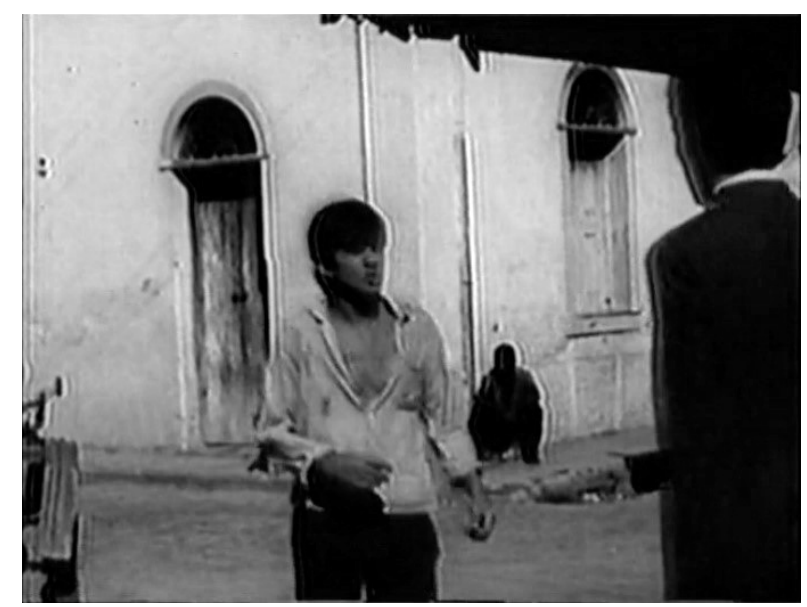

Figure 5: On José's first visit to the town, the environment is lit with a diffuse light. (C) Carlos Hugo Christensen Produçoẽs Cinematográficas.

As the flashback progresses, José recounts a horseback ride he takes with Zeca through the hills of the town. During this sequence, it is clear that Christensen uses cinematic language to emphasize similarity. Firstly, Christensen directs the viewer towards visual symmetry and corresponding clothing (Figure 6). Shadow, so clearly the signifier of division and difference in the film's first half, typically falls in an even and homogenizing way on bodies, faces, and scenery. The avoidance of structure and division also extends to set choice and location, as the pastoral setting has none of the geometric lines that cut across the town; instead, unruly foliage, wandering country tracks, and broad, open skies predominate. Christensen also introduces two new types of shot: very wide shots and Dutch tilts. These angles help to infuse the sequence with an unmistakable sense of energy; however, they also deprivilege the characters. In one particularly empty shot, for example, the riders occupy little more than a quarter of the frame as they move across it; combined with their rapid movement through the fields, the audience would arguably struggle to work out who is who (Figure 7). Equally, the very wide shots present the viewer with an expansive 
view of the countryside, but this means that at points the pair become difficult to distinguish from the vegetation. This communicates, to a degree, a loss of selfhood; at least, it suggests the wind-riding as an intense, energetic, affective experience. Not only do José and Zeca take part in the dramatic sensory experience of riding through the driving wind; crucially, they are for the viewer the sole visual signifiers of the wind's movement. I would suggest that the sequence represents their experience in terms of simile and metaphor; that is, where José and Zeca ride like the wind (i.e., fast), to a viewer they also are the wind, to the extent that their movement across the screen stands in for the movement of the wind itself. Throughout this first flashback sequence in the second part of the film, the visual language of camerawork and shot composition privileges similarity over difference, diminishing the significance of those differences, and even goes so far as to imply that the two riders' trip on horseback involves the dissolution of individual bodies into the greater whole of nature.

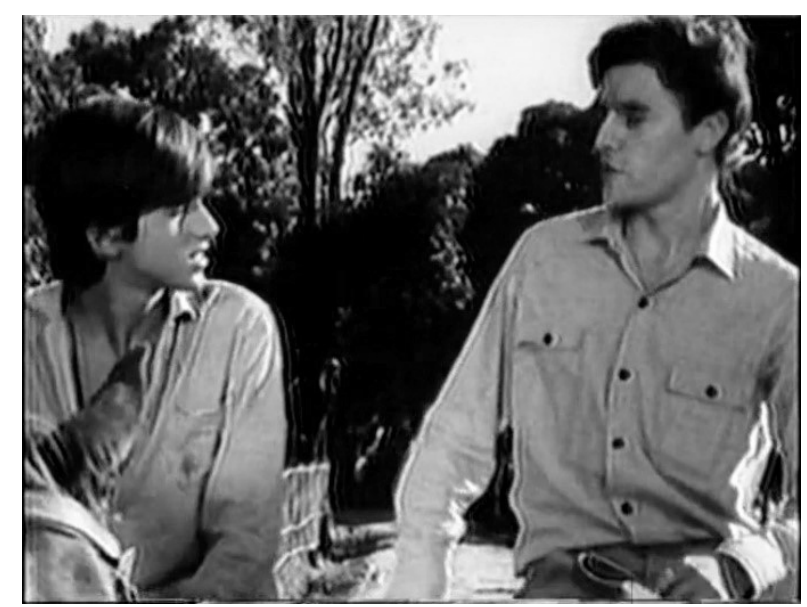

Figure 6: As José and Zeca ride through the countryside, their visual similarity alludes to an emotional intimacy.

(C) Carlos Hugo Christensen Produçoẽs Cinematográficas.

The audience might understand José and Zeca's experiences as evidence of bonding and the similarity created by the camerawork as a way of indicating their emotional proximity. I would add, however, that the pair exhibit the kind of homosexual desire that Bersani finds in The Immoralist; his interpretation of the quasi-mystical activity of Gide's narrator can help shed light on the confluence 
of identity loss, communicated through visual language, and ambiguous samesex desire. To clarify, Bersani examines how the narrator, Marcel, finds inspiration in the vitality of the Arab boys around him, a fact expressed in the first instance as desire for his own health. Rather than reaching out to possess the boys (as a self reaching out to another), he treats the boys as part of himself, as "a kind of sensualized ideal ego that beguiles him back to health" (Bersani, Homos 119). In other words, homosexual desire manifests as, or leads to, a duplication of Marcel's own ego outside his body. Later, the boundaries of his ego are simultaneously extended into the world and broken down; as Bersani writes, "his authentic being - his naked flesh — extends itself into the world, abolishing the space between it and the soil, the grass, the air" (120). While Christensen may simply seek to communicate the similarity of José and Zeca as an allusion to homoerotic desire, his film also becomes amenable to a Bersanian reading of self-expansive self-loss when cinematography dissolves the difference between José and Zeca, subsuming them within the natural landscape, while at the same time establishing this sensory immersion as pleasurable and ecstatic.

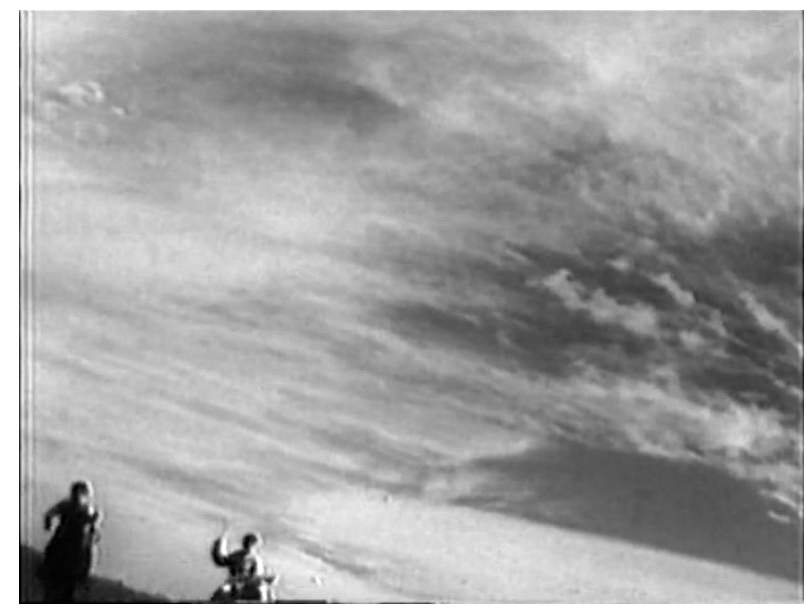

Figure 7: Dutch tilt shots help convey speed and movement. (C) Carlos Hugo Christensen Produçoẽs Cinematográficas.

Later, José and Zeca walk through the scrubland half naked while discussing climate and weather systems. Here one could point out that their relationship is inflected with a sense of hierarchy: José teaches Zeca, in the process adopting a mentoring role that would seem to put him in a position of power over the boy. 
This is technically true, but throughout the sequence visual similarity is redoubled as costume choices and lighting encourage a viewer to note their corporeal similarity, rather than their difference (Figure 8). At one point, as they talk, the camera stands in for José's gaze, and the viewer is shown an image of Zeca, naked from the waist up (Figure 9). In the previous shot, the focus falls on the midground, but here the camera focuses on the foreground while its depth of field is reduced, emphasizing Zeca. His flesh is heavily contoured by the lighting, and this eroticizes his body while also working to flatten the background further. Together with the foreground focus, this creates the illusion that Zeca's figure has been lifted out of the shot. This effect is exaggerated by the framing, which cuts his torso off at its base. Taken together, the shot might be read as signifying José's desire for Zeca, that is, his positioning as an eroticized object. But rather than indicate submission or deference in relation to this gaze, Zeca returns it reciprocally by gazing at the camera.

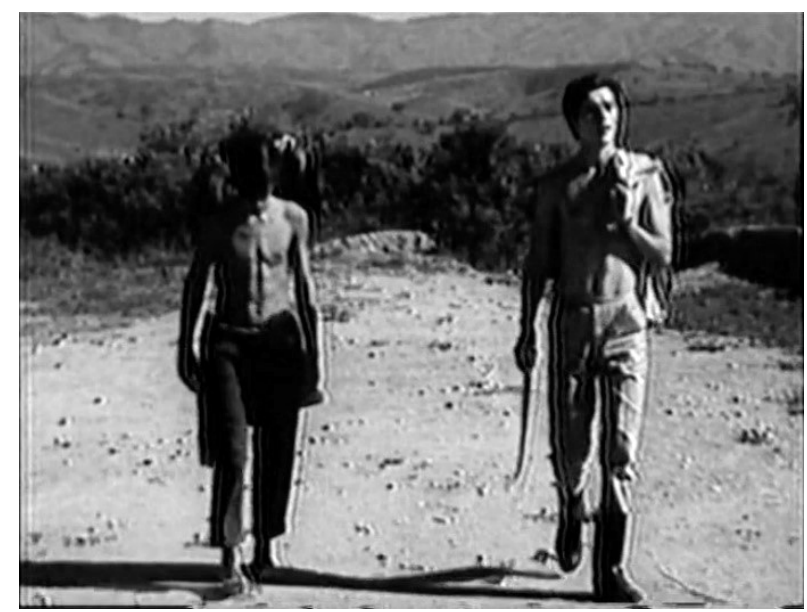

Figure 8: José and Zeca walk through the scrubland together. (C) Carlos Hugo Christensen Produçoẽs Cinematográficas

The sense that José might simply be objectifying Zeca is mitigated somewhat by the fact that the viewer is invited to gaze on the bodies of both figures moments before. Indeed, if Zeca's body has already been established as "same" to José, the camera's subsequent isolation of what might be called an eroticized bodily sameness, conjoined with a reciprocal gazing structure between the two characters and the sense of their growing emotional intimacy, presents 
homosexual desire not through a subject-object hierarchy but as desire mediated most precisely by Zeca's similarity to the viewer (José). The differences between them are constantly undercut, bracketed as unimportant or supplementary to the articulation of a desire that takes place between like selves. It is in this sequence that Christensen's film offers a cinematic analogy for homo-ness: the self desires the same while the other, relegated to the background, is left unthreatened.

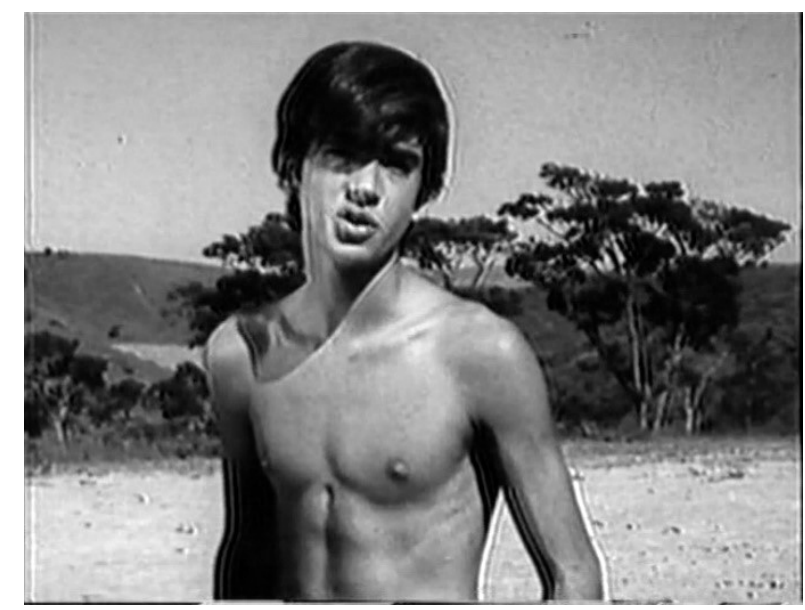

Figure 9: Camerawork draws attention to Zeca's body. (C) Carlos Hugo Christensen Produçoẽs Cinematográficas.

This configuration is echoed through the viewer's position; in this sequence (and in this half of the film more broadly), we witness the growing desire between the two men. Beyond this, we are offered opportunities to identify with both José and Zeca - to see from their perspectives - and to view the other as desirable (notable when, later on in the flashbacks, the camera takes up José as object of Zeca's gaze). If José is generally set up as an object for scrutiny in the first half of the film, in the second the possibilities for identification with him and desire for him begin to proliferate. At least, the sense of openness in this half contrasts strongly with the restrictions of the first, connoting a general sense of freedom.

\section{Slippages of Desire}

So far, Bersani's concept of homo-ness has helped illuminate some of $O$ menino $e$ vento's stylistic aspects, particularly in the second half of the film. It is also 
useful for making sense of character psychology, in particular when José gives an account of his relationship with Zeca.

When the court eventually asks José to defend himself, he begins by outlining his motivations. He claims to be "apaixonado pelo vento." His proffered explanation for this passion is childhood trauma. He says he was raised by an emotionally turbulent family of artists and writers- - Aos quinze anos já assistia a todas as amarguras, dramas e sofrimentos em que viviam todas aquelas pessoas que eu amava"-but rejected this heritage when he was fifteen and trained to be an engineer: "Assim, jurei que seria um homem prático." José presents his career choice as a philosophical dedication to the refusal of some unspecified creative or emotional "abismo" but also as a denial of a part of himself; he avoids the painful chaos of a creative life by turning to cold, hard logic. The sense of (emotional) repression is echoed when he describes his desire for the wind as a "fascinação remota," that is, a phenomenon both internal to him and distant from his project of rationality. From this explanation, the audience surmises that José's interaction with the wind and his attachment to Zeca are in some way expressive of a desire to connect with a buried aspect of himself. In that sense, the line between what the wind represents and José's repressed past self is curiously blurred, given a narcissistic tinge.

This blurring takes on a homoerotic dimension as José's testimony continues. We learn that he began to repress his creative or irrational tendencies at fifteenthe same age as Zeca - which subtly frames Zeca as in some way a vessel for the return of those repressed tendencies, a framing, as mentioned above, redoubled by the similarity in their names. Then, José openly confuses the wind with the boy: "Minha mente começou a confundir menino e vento. Não sabia se o vento vinha porque Zeca estava, ou se Zeca aparecia porque o vento ventava." If Zeca and the wind are taken as the same entity, José's passion for the wind (he is after all "apaixonado pelo vento") seems to slip into passion for Zeca, and back again, a confusion which colors José's experience with homoeroticism. Homo-ness helps us make sense of how the wind offers José the chance to access a longrepressed part of himself. After all, the self-effacing narcissist does not pursue the other for "that missing something," the object of desire, but instead seeks in the other what he already knows - a version of his own self. Reading these statements in light of Bersani's work suggests that Zeca plays a role similar to that of the beautiful youths who beguile Gide's narrator back to health. Rather 
than externalized objects of desire, the narrator treats them as parts of his own ego. In a similar way, Zeca facilitates José's communion with himself. At the very least, it is clear José's narrative gradually elides the distinction between himself, the wind, and Zeca, whereby a purportedly innocent passion for the wind blends into a desire for Zeca, which blends into a desire for himself.

José explains how he runs to the summit of a hill in order to fully experience the sensory stimulation of a strong gust of wind, and in doing so undergoes an ecstatic experience. José's narration details an experience that is both solipsistic and transformative of his sense of self. He says, "eu estava sozinho perdido na corrente," and here I read his "eu" in psychological terms as referring to his ego. Alone and lost in the wind's current, José then describes how he manages to reach various locations, including far-off "campina" and "lagoa," as the wind somehow carries or expands his sense of self over vast geographical distances. The sequence presents a montage of close-up shots of José's face, each shot lit differently (either in low-key or in high-lighting). The montage suggests to the viewer a variation in place, even though a tree trunk included at roughly the same position in each frame also confirms to us that José does not physically move. Rather, the montage lyrically conveys his mystical, psychological voyage. Bersani's model helpfully illuminates the film here by highlighting how José's "eu" is both expanded and lost, "perdido." José's is no longer a neatly contained person, at least not according to a Bersanian view, but rather psychologically extended outside his body, touching all manner of geographical locations. José approximates, perhaps, an aerial version of Gide's desiring skin, less a discrete, definable self and more "the contact between himself and the world" - a state of being that through loss of containment and definition becomes better defined by expanding connectivity (Homos 120). This becomes more explicitly homoerotic when Zeca finds José deep in a wind-induced ecstasy: he strips his clothes off and embraces José. Their embrace counts as the most overt description of homosexuality in the film. It is also a moment where "homosexuality" is perhaps least applicable as a descriptor: José's personhood has seemingly spread about the world, thinned to near-total dissolution; Zeca is himself a proxy for the wind; and the wind is but a synecdoche for José's ego. The intense, unusual cinematic language - the strange swirling motion produced by the camera's tight pan-andtilt movement, the grating sound of the wind - disorients the viewer and forces us to review what we are seeing. Bersani's theory helps us make sense of this 
disorientation and suggests we take the image of two men in passionate embrace as holding a wealth of slippage between identities, persons, objects, and subjects.

The difference in configuration of homosexuality between Mário and José is perhaps clearer now. Mário violently protects his personhood, closeting his identity in order to preserve his position in society and uphold a violent status quo. Even the community he seeks with José is hierarchical, founded on oppositional relations between self and other, a "normais" and a "nós." In José's more radical formulation of homosexual desire, personhood is discarded in order to encounter selfhood elsewhere, outside the body, forming a strange and ambiguous sameness of being. Hierarchical forms of being that reinforce and protect the "community" have been sidestepped for a non-oppositional, nonaggressive relational mode, the consequences of which I now explore.

\section{Conclusion: Lawless Pederasty}

I began by arguing that $O$ menino e o vento contrasts Mário's homosexuality with José's experience of homo-ness, both of which are driven by homosexual desire but to quite different ends. The trial attempts to resolve José's sexual identity in concrete terms - as straightforward homosexuality - and so to convict him of murder. The desiring relations into which José enters, however, cannot be resolved in a straightforward way; nothing legible as "homosexuality" can be found. In his final statement, José declares, "por que não admitir que ele tenha vindo com este vento e já esteja subindo pela escada?" at which point the wind forces the courthouse doors open and ascends the stairs to the courtroom, scattering the assembled townspeople and ruining the proceedings. This chaos can be read as a demonstration of the capacity of homo-ness to overturn the social order, or of its radical quality. Homo-ness is a rejection of fixed and legible subjectivity (required for the law to operate), which provides it a broad basis for resistance to heterosexist and patriarchal structures. Given that social order is constructed from self-other relations, homo-ness presents nothing less than a total disruption to, and separation from, all existing structures of community. As Bersani claims, "between oppression now and freedom later there may have to be a radical break with the social itself" (Homos 176).

Problems can be found with homo-ness, both in Bersani's theory and in the film. The final scene's violence suggests the initial break will be a terrifying step. 
Bersani writes that the narrator of The Immoralist, Marcel, "risks his own boundaries, risks knowing where he ends and the other begins" (Homos 12829) - a risk perhaps implied by Christensen's film when Zeca disappears for extended periods of time. As radical and politically transgressive as it might appear, ecstatic self-loss here makes the homosexual subject vulnerable, putting it at risk of destruction. Furthermore, Bersani admits his thesis is chiefly concerned with charting a path out of heteroized relations rather than offering a complete vision of what a community based on same-ness would look like (Homos 177). Alan Sinfield, on the other hand, suggests Bersani goes too far in valorizing transgression as a mode of resistance for queer people, a point that rests on whether one accepts self-other relations as inherently violent or not (142). For Sinfield, self-immolatory acts like homo-ness do not produce social change and indeed smack of a certain unrealistic, bourgeois romanticism.

One may also criticize the unsatisfactory way in which $O$ menino e o vento considers material relations. The main difference between José and Zeca is material: the former is a rich city-dweller, a trained engineer, and a careerist, while the latter is poor, works as a porter, and cannot read. In other words, José can disappear into ego-extensive ego-loss because he can afford to do so. Since he is initiated into homo-ness during a holiday, the whole practice might be dismissed as a leisure activity, which jars with the notion of self-divestiture central to Bersani's thesis. Karl Posso has pointed out this problematic relation between self-loss and social class, arguing that although Marcel embraces psychic and material self-divestiture, the boys to whom he only paid a trifle were infinitely poorer than Marcel himself; thus, homo-ness for them is actually an experience of remuneration. According to this argument, the radical transformation of self-other relations is also effectively a commodity (105).

Christensen's version of Gidean pederasty is no straightforward utopian solution for social oppression, and that material inequalities remain uncontested in the film. Nevertheless, as Bersani says, "if a community were ever to exist in which it would no longer seem natural to define all relations as property relations [...] we would first have to imagine a new erotics" (Homos 128). As I have argued here, $O$ menino e o vento contributes to that reimagining. Despite its flaws, the film's formulation of homosexuality remains radical for its time. The "entendido" identity was more or less replaced by a "gay" identity in the 1970s, which, following the post-Stonewall Gay Power movement, began to make the 
strides towards the visibility of sexual minorities in Brazil that the entendido could never achieve (nor would necessarily wish to approximate). With this in mind, the film offers a cautionary tale for the incipient movement of identarian politics: any conceivable identity that does not at least recognize its complicity with a social order structured on an antagonistic relation to the other is doomed, like Mário, to remain in and repeat structures of oppression.

\section{Works Cited}

Balderston, Daniel. "The Fecal Dialectic: Homosexual Panic and the Origin of Writing in Borges." Entiendes? Queer Readings, Hispanic Writings, edited by Emilie L. Bergman and Paul Julian Smith. Duke UP, 1995, pp. 29-45.

Bersani, Leo. Homos. Harvard UP, 1995.

-. Thoughts and Things. U of Chicago P, 2015.

Borges, Jorge Luis. El informe de Brodie. Debols, 1970.

Christensen, Carlos Hugo, director. A intrusa. Christensen Produções Cinematográficas, 1979.

—. O menino e o vento. Christensen Produções Cinematográficas, 1977.

Gallina, Mario. Carlos Hugo Christensen: historia de una pasión cinematográfica. Iturbe, 1997.

García, Carlos. "Carlos Hugo Christensen, revelación del melodrama." Cine argentino, la otra historia, edited by Sergio Wolf. Letra Buena, 1994, pp. 41-63.

Green, James N. Beyond Carnival: Male Homosexuality in Twentieth-Century Brazil. U of Chicago P, 2001.

Hodgson, James. Male Homosexuality in Brazilian Cinema of the 1960s and 1970s. 2013, U of Manchester, PhD dissertation.

-. "Queer Possibilities in Glauber Rocha's Barravento." Studies in Spanish and Latin American Cinema, vol. 15, no. 1, 2018, pp. 25-43.

Machado, Aníbal. "O iniciado do vento." A morte da porta-estandarte e outras histórias. J. Olympio, 1965, pp. 3-34.

Melo, Adrián. Otras historias de amor: gays, lesbianas y travestis en el cine argentino. Lea, 2008.

Miller, David A. “Anal Rope.” Representations, vol. 32, no. 32, 1990, pp. 11433. 
Moreno, Antonio. A personagem homossexual no cinema brasileiro. Funarte, 2001.

Nagel, Joane. "Masculinity and Nationalism: Gender and Sexuality in the Making of Nations." Ethnic and Racial Studies, vol. 21, no. 2, 1998, pp. 24269.

Neto, João Nemi. Anthropophagic Queer: A Study on Abjected Bodies and Brazilian Queer Theory in Literature and Film. 2015, City U of New York, $\mathrm{PhD}$ dissertation.

Perlongher, Néstor. O negócio do michê: prostituição viril em São Paulo. Brasiliense, 1987.

Place, Janey A., and Lowell S. Peterson. "Some Visual Motifs of Film Noir." Film Comment, vol. 10, no. 1, 1974, p. 30.

Porfirio, Robert, Alain Silver, and James Ursini. Film Noir Reader. Limelight, 1996.

Posso, Karl. Artful Seduction: Homosexuality and the Problematics of Exile. Legenda, 2003.

Rowland, Clara, and Estela Vieira. "Introduction: On Portuguese Cinema." Journal of Lusophone Studies, vol. 2, no. 1, 2017, pp. 1-5.

Ruffinelli, Jorge. "Bajo cinco banderas: el cine multinacional de Carlos Hugo Christensen." Nuevo Texto Crítico, vol. 11, no. 1, 1998, pp. 277-325.

Schoonover, Karl, and Rosalind Galt. Queer Cinema in the World. Duke UP, 2016.

Silva, Simone Cavalcante da. "The Space of Queer Masculinities in Karim Aïnouz's Praia do futuro." Space and Subjectivity in Contemporary Brazilian Cinema, edited by Antônio Márcio da Silva and Mariana Cunha. Springer, 2017, pp. 169-83.

Sinfield, Alan. Gay and After. Serpent's Tail, 1998.

Subero, Gus. Queer Masculinities in Latin American Cinema: Male Bodies and Narrative Representations. I.B. Tauris, 2013.

Thompson, Currie K. "Two Takes on Gender in Argentine Film Noir." Studies in Hispanic Cinemas, vol. 4, no. 2, 2008, pp. 121-30.

Trevisan, João Silvério. Perverts in Paradise. Alyson, 1986.

Warner, Michael. Fear of a Queer Planet: Queer Politics and Social Theory. U of Minnesota P, 1993. 